theories of mortality. In preparing this paper he was helped by his considerable knowledge of the science of biology, a subject in which he was always deeply interested. He was a Fellow of the Royal Zoological Society, taking a keen interest in its work.

On leaving College in 1930, he started his actuarial career with the Equity \& Law. Five years later he moved to the Medical Sickness Society and was appointed Assistant Actuary in 1944, Actuary in 1956, and General Manager in 1959. In 1958 he played a leading role in founding the Permanent Insurance Company with the object of offering non-cancellable Sickness and Accident Insurance, always a speciality of the Medical Sickness, to those not qualified to join that Society which limits its members to doctors and dentists. As Manager of that Company from its inception to his death, he witnessed not only its growth but also the entry of many other companies into the permanent health insurance field, a development which he always welcomed being convinced of the great need for this type of insurance. He was always ready to assist professional colleagues from his unrivalled experience in this specialized field. When in 1968 the Life Offices' Association formed a Permanent Disability Committee he became the first Chairman.

From 1965 he was British Delegate for Sickness Insurance to the British Insurers European Committee, a task to which he devoted much time and effort being convinced that it was most important to explain to members of the committee from other parts of Europe the way in which this class of insurance was conducted in the U.K. In this work he was able to make good use of his linguistic abilities and, although able to speak several languages fluently, he was always interested in learning more and had recently been attending classes in Japanese.

A close connexion with members of the medical profession combined with an interest in biological matters naturally led him to take a keen interest in mortality and morbidity statistics and in particular in the possibility of deriving valuable information from the vast statistical material available from a large sickness and accident insurance fund. In 1952 he collaborated with Prof. J. N. Morris, M.R.C.P., D.P.H., and Mr J. A. Heady, M.A., of the Medical Research Council in writing a paper on Coronary Heart Disease in Medical Practitioners which was published in the British Medical Journal.

Quite apart from his professional work he was a man of many interests, being an artist and musician of no mean ability and a keen photographer. He also took much interest in his garden, particularly growing roses. Mr Barley leaves a widow, two sons and two daughters. He died when he still had much to contribute both to his office and to the Institute of which he was such a loyal servant.

G. J. KNAPMAN

\title{
COLIN STRATHERN PENN
}

COLIN PENN came from an insurance family as his father was Glasgow Secretary of the English and Scottish Law Life Assurance Company. After leaving school, Larchfield Academy, Penn commenced his actuarial career in Glasgow where he joined the Scottish Amicable Life Assurance Society in 1909. He qualified as a Fellow of the Faculty in 1913 and served in the actuarial department of the Scottish Amicable until the outbreak of war in 1914. He had a distinguished war service and was awarded the Military Cross while serving with the Cameron Highlanders, for which regiment he always retained a very warm regard. On his return from war service he continued his actuarial studies and qualified as a Fellow of the Institute of Actuaries in 1919. He was promoted to be 
Assistant Actuary of the Scottish Amicable in 1921. As with his regiment, he always maintained an affectionate interest in his first company.

His career with the Scottish Life commenced with his appointment as Actuary of the company in 1922. In 1934 he became Secretary and in 1946 General Manager, a position which he occupied for 10 years. He will be remembered in the Scottish Life in many ways, for his genuine interest in the personal and company activities of his colleagues, for his quick grasp of any problem put to him, and for his encouragement of his younger associates. He had a remarkable memory for statistics and took a special joy in general elections and cricket test matches. He knew all the constituency records and current members, and at election time obtained much pleasure in seeing how closely his forecasts compared with the results achieved. For cricket he had a great love and when the Australian tours were taking place his colleagues could forecast with remarkable accuracy when Penn would be visiting his Branches at Nottingham, Leeds, Manchester and London. In his retirement he continued these interests through the medium of television.

He was Chairman of the Associated Scottish Life Offices from 1952-54 and in his earlier days, before there was a full time Secretary, acted as Honorary Secretary.

He was a loyal and strong supporter of the Faculty throughout his insurance career and gave devoted service from 1921 until 1952 as an Office bearer, Council member and as a Tutor and Examiner, serving as Chairman of the Board of Examiners from 1928 to 1930. He was elected President of the Faculty for the immediate post-war years 1946-48. His election at this time was a particularly appropriate one. He had vivid personal recollections of the severe toll of the First World War-a point to which he referred in his Presidential Address-and he was particularly sympathetic to the difficulties of the younger actuaries in their resumption of their civilian profession. Under his guidance the Faculty enthusiastically resumed its full range of activities.

Penn took a keen interest in the formation of the Students' Society in 1920 and was one of the nine members of the original Committee elected by the Faculty. It is interesting to note that three members of this original Students' Society Committee eventually became Presidents of the Faculty-Penn himself, the late A. R. Davidson, and R. L. Gwilt.

In actuarial matters Penn's keenest interest undoubtedly lay in the field of mortality research, possibly due to the influence of his colleague the late Lewis P. Orr. Production of the A1924-29 Mortality Tables was entrusted to Committees of the Faculty and the Institute and Penn was one of the three members of the Faculty Committee. When the Faculty and Institute Joint Permanent Mortality Investigation Committee was set up in 1931, Penn was one of the original members nominated by the Faculty, and he remained a member until the conclusion of his Presidency in 1948. In his business life this interest manifested itself in his active participation in underwriting of new proposals. During his tenure of office as General Manager and as Secretary of the Scottish Life, Penn conducted the underwriting of all new business along with the Company's Principal Medical Officer, his old friend and colleague Dr A. Fergus Hewat, himself the son of a former President of the Faculty, Archibald Hewat. This happy association bore fruit beneficial to the Faculty in that in 1954 Penn and Hewat produced a paper for the Faculty entitled 'Life Assurance Underwriting', on which there was a very full and informed discussion.

Reference has already been made to Penn's membership of the original Committees of the Continuous Mortality Investigation and of the Students' Society but he did not confine his actuarial interests to technical subjects. He always enjoyed a fine wine and a 
tastefully selected meal, and it was fitting that he should also be a member of the original Committee of the Scottish Actuaries' Club of which he became Chairman in 1948 after completion of his Presidential term of office. These three 'firsts', if they may be so termed, typify Penn's chief actuarial interests-namcly, the Faculty and its future, the investigation of mortality problems, and the friendship of his fellow actuaries.

J. G. WALLACE 